REPORTS OF MORPHOLOGY
$\begin{gathered}\text { Official Journal of the Scientific Society of Anatomists, } \\ \text { Histologists, Embryologists and Topographic Anatomists } \\ \text { of Ukraine } \\ \text { journal homepage: https://morphology-journal.com }\end{gathered}$

\title{
Analysis of risk factors and stroke structure according to the hospital register of clinics in Vinnytsia for 2017-2019
}

Fiks D. 0 .

National Pirogov Memorial Medical University, Vinnytsya, Ukraine

\section{ARTICLE INFO}

Received: 12 December, 2019

Accepted: 14 January, 2020

UDC: $616.71007 .234: 577.161 .2$

\section{CORRESPONDING AUTHOR \\ e-mail: d.fix@i.ua}

Fiks D.O.
Due to the analysis of a whole set of indicators of the quality of medical care for acute cerebrovascular accident (ACA), and above all, the identification of major shortcomings in the maintenance of stroke register, it is possible to reduce morbidity, mortality and disability from this nosology. The purpose of the work is to study and compare the structure and risk factors of stroke according to the hospitals of Vinnytsia for the period 2017-2019. The stroke register was created on the basis of medical documentation of hospitals of the municipal non-profit enterprise "Vinnytsia Regional Clinical Psychoneurological Hospital named after Academician O.I. Yushchenko of Vinnytsia Regional Council" (VRCPNH) and Vinnytsia City Clinical Hospital of Emergency Medical Services (VCCHEMS), which are the most typical for this region of Ukraine. Statistical processing of the results was performed using the licensed statistical package "Statistica 5.5" using parametric evaluation methods. Between the two medical institutions in Vinnytsia and in the dynamics of time there were significant differences in different age, sex, type of stroke contingent of patients. When comparing the data of the territorialpopulation register of stroke in hospitals in Vinnytsia in 2017-2019, it was found that in both studied institutions the percentage of young and middle-aged patients, especially men, increased. The percentage of young and middle-aged patients in VRCPNH is higher than in VCCHEMS. Modified risk factors, which are currently the most important medical and social problem, are analyzed. There were no significant differences in the dynamics of stroke in both hospitals. The percentage of patients who had a stroke in hospital has decreased over time. The meteorological dependence of stroke has been proved, which points to the importance of preventive measures for people at risk. The main shortcomings in the collection of anamnestic data are analyzed. Analysis of risk factors for stroke suggests that the disease is based on various causes.

Keywords: stroke, gender differences, stroke risk factors, register method.

\section{Introduction}

Acute cerebrovascular accident (ACA) occupies one of the leading places in the structure of vascular pathology of the brain. Stroke significantly reduces the duration, quality of life in the future and is associated with high material costs due to the high disability of surviving patients [8].

It is believed that stroke most often occurs in the elderly. In the next 10-15 years in economically developed countries, an increase in the incidence of stroke is expected due to an increase in the share of elderly people in the population [24]. The probability of getting ACA increases with age and, in fact, after 55 years, for every decade of life, it doubles. However, according to current data, only two thirds of vascular accidents occur in patients older than 60 years. And along with this there is a tendency to "rejuvenate" this pathology.
One third of ACA falls on the age period of 20-60 years [9, 13].

According to world statistics, hemorrhagic strokes are more common in young patients and ischemic strokes in the elderly. Females are more likely to have ischemic strokes, and men are more likely to have hemorrhagic strokes. There is no other gender division in strokes. Gender does not affect the severity of the condition and the quality of recovery after this pathology - it all depends on the time, adequacy of care, individual characteristics of the body and comorbidities $[4,24]$.

A number of studies have described the seasonality of ACA development. This concept is understood as regular fluctuations in the incidence rate during a calendar or epidemic year, due to long-term timing of rises and falls in 
its levels in certain months and seasons [5, 23, 25]. The trigger for the development of ACA may be physiological processes associated with changes in weather. We can assume the influence of external and internal triggers of its development in the time period preceding the onset of stroke, and this is of great importance for prevention in a particular region $[3,19,20]$.

Despite the priority of stroke prevention, most countries do not have reliable information on epidemiological indicators such as the incidence of atrial fibrillation and carotid artery stenosis. These are nosologies, a change in the approach to diagnosis and treatment of which affects the risk of stroke $[1,6]$. Thus, the course of atrial fibrillation and carotid artery stenosis is difficult to predict - the process can progress very rapidly or slowly, or be stable for many years. Dispensary accounting and choice of treatment tactics for both "asymptomatic" and "symptomatic" patients is extremely important $[2,8,16]$.

The prognosis for a patient with acute cerebrovascular accident largely depends on the timeliness of medical treatment. The time factor plays a significant role in both hemorrhagic and ischemic stroke. Modern doctors need to provide qualified medical care to a patient with a stroke as soon as possible, including neuroimaging diagnosis and aggressive treatment with thrombolytic therapy [18]. However, the situation may be complicated by the fact that among strokes there is a certain proportion of cases that are asymptomatic or may occur during treatment for therapeutic and surgical pathology. With timely hospitalization in specialized neurological departments, the mortality of patients in the acute period of stroke and the degree of disability is much lower than those who stayed at home or were hospitalized in a non-specialized department or transferred to a specialized department in a few days [15].

Thus, when registering, it is important to record data on the percentage of patients who had a stroke in the hospital (patients were transferred to a special hospital from other departments), who have cardiac arrhythmias and carotid artery stenosis. In addition, the formal entry of information about the time (month, season) of the symptoms of acute cerebrovascular accident and age at the time of hospitalization is unacceptable.

The purpose of the work is to study and compare the structure and risk factors of stroke according to the data of hospitals in Vinnytsia for the period 2017-2019.

\section{Materials and methods}

Data on cases of stroke were obtained on the basis of medical documentation of medical institutions (for 20172019), which are the most typical for the selected region of Ukraine, namely the municipal non-profit enterprise "Vinnytsia Regional Clinical Psychoneurological Hospital named after Academician O. I. Yushchenko of Vinnytsia Regional Council" (VRCPNH) and Vinnytsia City Clinical Hospital of Emergency Medical Services (VCCHEMS). In each hospital, data collection and processing were
Table 1. Distribution of men and women with ACA in stroke unit of VRCPNH or VCCHEMS for 2017-2019.

\begin{tabular}{|c|c|c|c|c|}
\hline \multirow{2}{*}{$\begin{array}{l}\text { Groups } \\
\text { surveyed }\end{array}$} & \multirow{2}{*}{$\begin{array}{l}\text { Years of } \\
\text { research }\end{array}$} & \multirow{2}{*}{ Sex } & \multicolumn{2}{|c|}{ Hospitals } \\
\hline & & & VRCPNH & VCCHEMS \\
\hline \multirow{6}{*}{ General } & \multirow{2}{*}{2017} & men & 307 & 351 \\
\hline & & women & 209 & 335 \\
\hline & \multirow{2}{*}{2018} & men & 312 & 310 \\
\hline & & women & 187 & 306 \\
\hline & \multirow{2}{*}{$\begin{array}{c}10 \text { months } \\
2019\end{array}$} & men & 287 & 182 \\
\hline & & women & 175 & 163 \\
\hline \multirow{6}{*}{$\begin{array}{l}\text { Ischemic } \\
\text { stroke }\end{array}$} & \multirow{2}{*}{2017} & men & 269 & 308 \\
\hline & & women & 184 & 296 \\
\hline & \multirow{2}{*}{2018} & men & 267 & 276 \\
\hline & & women & 166 & 282 \\
\hline & \multirow{2}{*}{$\begin{array}{l}10 \text { months } \\
2019\end{array}$} & men & 248 & 162 \\
\hline & & women & 152 & 153 \\
\hline \multirow{6}{*}{$\begin{array}{l}\text { Hemorrhagic } \\
\text { stroke }\end{array}$} & \multirow{2}{*}{2017} & men & 37 & 42 \\
\hline & & women & 25 & 39 \\
\hline & \multirow{2}{*}{2018} & men & 45 & 34 \\
\hline & & women & 21 & 24 \\
\hline & \multirow{2}{*}{$\begin{array}{c}10 \text { months } \\
2019\end{array}$} & men & 39 & 20 \\
\hline & & women & 23 & 10 \\
\hline
\end{tabular}

performed by a certified neurologist. The obtained data and their reliability were checked in the journals of patients and the bureau of medical and social examination. The RES-Q report form was completed on a case-by-case basis - a special report forms in an international program developed by the European Stroke Society (ESO) ESOEAST initiative. Data on the initial examination and medical history of the patient were recorded, the place (in the hospital, not in the hospital) and the time of year of the stroke were indicated. Atrial fibrillation, carotid artery stenosis was considered if their history was recorded.

Quantitative distribution of patients with ACA in stroke block of VRCPNH or VCCHEMS are presented in table 1.

Statistical processing of the results was performed using the licensed statistical package "Statistica 5.5" using parametric evaluation methods.

\section{Results}

When comparing the percentage of patients who had a stroke before the age of 40, in VRCPNH found significantly $(p<0.05)$ greater in patients with ischemic stroke and less - with hemorrhagic stroke (in $2017-1.4 \%$ in women in general and $1.6 \%$ with ischemic stroke; in $2019-3.6 \%$ in men with ischemic stroke and $0 \%$ with hemorrhagic stroke) compared with VCCHEMS (2017 - 0\% in women in general and $0 \%$ with ischemic stroke; in $2019-0.6 \%$ in men with ischemic stroke and $10.0 \%$ with hemorrhagic stroke).

In VRCPNH, the percentage of patients under the age of 40 in 2019 was significantly $(p<0.05)$ higher than in 2018 (in 
$2018-0.5 \%$ in women in general and $0.6 \%$ with ischemic stroke; in $2019-3.4 \%$ in women in general and $3.9 \%$ with ischemic stroke). In VCCHEMS also over time significantly $(p<0.01-0.001)$ increased the percentage of patients of this age $(2017-0 \%$ in women in general and $0 \%$ with ischemic stroke; in $2018-0.7 \%$ in women in general; $2019-1.2 \%$ in women in general and $1.3 \%$ with ischemic stroke).

In VRCPNH, the percentage of patients with ischemic stroke at the age of $41-50$ years was significantly $(p<0.05)$ higher (2019 - 7.4\% in women in general and $8.1 \%$ with ischemic stroke) compared with VCCHEMS (2019 - 2.5\% in women in general and $2.0 \%$ with ischemic stroke). In VRCPNH in 2019 the percentage of women with ischemic stroke was significantly $(p<0.05)$ higher, and in women with hemorrhagic stroke had a tendency $(p=0.063)$ to lower values compared to 2017 (2017 - 3.3\% in women with ischemic stroke and $24.0 \%$ with hemorrhagic stroke; in $2019-7.9 \%$ of women with ischemic stroke and $4.3 \%$ with hemorrhagic stroke).

The percentage of patients who had a stroke at the age of $51-60$ years in VRCPNH is significantly $(p<0.05-0.001)$ higher (2017 - $27.7 \%$ in men in general, $26.4 \%$ with ischemic stroke, $23.0 \%$ in women in general, $21.2 \%$ with ischemic stroke and $36.0 \%$ with hemorrhagic stroke; in $2018-30.8 \%$ in men in general and $30.3 \%$ in ischemic stroke, $20.3 \%$ in women in general and $21.1 \%$ with ischemic stroke, in 2019 $-33.4 \%$ in men in general and $32.7 \%$ with ischemic stroke, $18.3 \%$ in women in general and $38.5 \%$ with hemorrhagic stroke) compared with VCCHEMS (2017 - 19.1\% in men in general and $17.9 \%$ with ischemic stroke, $7.5 \%$ in women in general, $6.8 \%$ with ischemic stroke and $12.8 \%$ with hemorrhagic stroke; in $2018-19.4 \%$ in men in general and $18.1 \%$ with ischemic stroke, $11.8 \%$ in women in general and $1.7 \%$ with ischemic stroke; $2019-16.5 \%$ in men in general and $16.7 \%$ with ischemic stroke, $6.7 \%$ in women in general and $0 \%$ with hemorrhagic stroke).

In VRCPNH, the percentage of women with ischemic stroke aged 51-60 years in 2019 was significantly $(p<0.05)$ lower compared to 2017 and 2018 (respectively $11.8 \%$ $21.2 \%-14.3 \%)$. In the same medical institution, the percentage of women with hemorrhagic stroke aged 51-60 years in 2019 was significantly $(p<0.05)$ higher than in 2018 (60.9\% and $14.3 \%$, respectively). In 2018 , the percentage of patients of this age was significantly $(p<0.001)$ higher than in 2017 and 2019 in VCCHEMS (in $2018-11.8 \%$ in women in general and $1.7 \%$ with ischemic stroke; in $2017-7.5 \%$ in women in general and $6.8 \%$ with ischemic stroke; in 2019 $6.7 \%$ for women in general and $7.2 \%$ with ischemic stroke).

The percentage of patients who had a stroke at the age of 61-70 years, in VRCPNH is significantly $(p<0.05-0.001)$ higher (in $2017-41.3 \%$ in men with ischemic stroke; in $2018-48.7 \%$ in women in general, $47.0 \%$ with ischemic stroke and $61.9 \%$ with hemorrhagic stroke; in $2019-44.6 \%$ in women in general and $46.1 \%$ with ischemic stroke) compared to VCCHEMS (in $2017-32.5 \%$ in men with ischemic stroke; in $2018-27.1 \%$ in women in general, $28.0 \%$ with ischemic stroke and $16.7 \%$ with hemorrhagic stroke; in $2019-28.8 \%$ in women in general and $28.1 \%$ with ischemic stroke).

In VRCPNH, the percentage of women with stroke aged $61-70$ years in 2017 was significantly $(p<0.01-0.001)$ lower compared to 2018 and 2019 (in $2017-28.2 \%$ in women in general, $28.8 \%$ with ischemic stroke and $24.0 \%$ with hemorrhagic stroke; in $2018-48.7 \%$ in women in general, $47.0 \%$ with ischemic stroke and $61.9 \%$ with hemorrhagic stroke; in $2019-44.6 \%$ in women in general and $46.1 \%$ with ischemic stroke).

The percentage of patients who had a stroke at the age of $71-80$ years in VRCPNH is significantly $(p<0.05-0.001)$ lower (in $2017-19.5 \%$ in men in general and $20.4 \%$ in ischemic stroke, $12.0 \%$ in women with hemorrhagic stroke; in $2018-13.8 \%$ in men in general, $14.6 \%$ with ischemic stroke and $8.9 \%$ with hemorrhagic stroke, $21.9 \%$ in women in general and $23.5 \%$ with ischemic stroke; in $2019-12.5 \%$ in men in general and $12.9 \%$ in ischemic stroke, $20.6 \%$ in women in general, $23.7 \%$ with ischemic stroke and $0 \%$ with hemorrhagic stroke) compared with VCCHEMS (2017 $29.9 \%$ in men in general and $32.2 \%$ with ischemic stroke, $35.9 \%$ in women with hemorrhagic stroke; in $2018-26.5 \%$ in men in general, $26.4 \%$ with ischemic stroke and $26.5 \%$ with hemorrhagic stroke, $38.2 \%$ in women in general and $39.4 \%$ with ischemic stroke; $2019-35.2 \%$ in men in general and $35.8 \%$ with ischemic stroke, $36.8 \%$ in women in general, $36.6 \%$ with ischemic stroke and $40.0 \%$ with hemorrhagic stroke).

In VRCPNH, the percentage of women with stroke aged $71-80$ years in 2017 was significantly $(p<0.05-0.001)$ higher than in 2018 and 2019 (2017 - 19.5\% for men in general, $31.6 \%$ for women in general and $34.2 \%$ with ischemic stroke; in $2018-13.8 \%$ in men in general, $21.9 \%$ in women in general and $23.5 \%$ in ischemic stroke; in $2019-12.5 \%$ in men in general, $20.6 \%$ in women in general and $12.9 \%$ with ischemic stroke). In VCCHEMS in 2018 and 2019, the percentage of patients of this age was significantly higher $(p<0.05)$ compared to the previous year $(2017-9.5 \%$ in men with hemorrhagic stroke; in $2018-26.5 \%$ in men in general and $26.4 \%$ with ischemic stroke; in $2019-35.2 \%$ in men in general, $35.8 \%$ with ischemic stroke and $30.0 \%$ with hemorrhagic stroke).

The percentage of patients who had a stroke over the age of 80 years in VRCPNH is significantly $(p<0.05-0.001)$ lower (in $2017-1.6 \%$ in men in general, $1.9 \%$ with ischemic stroke and $0 \%$ with hemorrhagic stroke, $9.1 \%$ in women in general, $10.3 \%$ with ischemic stroke and $0 \%$ with hemorrhagic stroke; in $2018-1.0 \%$ in men in general and $1.1 \%$ with ischemic stroke, $3.2 \%$ in women in general, $3.0 \%$ with ischemic stroke and $0 \%$ with hemorrhagic stroke; in $2019-0.7 \%$ in men in general and $0.8 \%$ in ischemic stroke, $5.7 \%$ in women in general and $6.6 \%$ with ischemic stroke) compared with VCCHEMS (2017 - 10.5\% in men in general, $10.7 \%$ with ischemic stroke and $9.5 \%$ with hemorrhagic stroke, $23.0 \%$ in women in general, $23.6 \%$ with ischemic 
stroke and $17.9 \%$ with hemorrhagic stroke; in $2018-11.3 \%$ in men in general and $12.0 \%$ with ischemic stroke, $19.6 \%$ in women in general, $18.8 \%$ with ischemic stroke and $29.2 \%$ with hemorrhagic stroke; in $2019-7.1 \%$ in men in general and $7.4 \%$ with ischemic stroke, $23.9 \%$ in women in general and $24.8 \%$ with ischemic stroke).

In VRCPNH, the percentage of women with stroke over the age of 80 in 2017 was significantly $(p<0.05-0.01)$ higher than in 2018 (2017 - 23.0\% in women in general and $23.6 \%$ with ischemic stroke; $2018-19.6 \%$ in women in general and $18.8 \%$ with ischemic stroke).

For VRCPNH in the sex comparison of the percentage of patients of a certain age group found: significantly $(p<0.05)$ greater in men under 40 years of age (2018 - 3.5\% in men in general), $41-50$ years (2018 - 10.6\% in men in general), 51 60 years $(2018-30.8 \%$ in men in general and $30.3 \%$ with ischemic stroke; in $2019-33.4 \%$ in men in general and $32.7 \%$ with ischemic stroke), $61-70$ years (2017 - $40.1 \%$ for men in general) compared to women of similar groups (up to 40 years $-0.5 \%$ for women in general in $2018 ; 41-50$ years $-5.3 \%$ for women in general in 2018 ; $51-60$ years $20.3 \%$ y women in general and $21.1 \%$ with ischemic stroke in 2018 and $18.3 \%$ of women in general and $11.8 \%$ with ischemic stroke in $2019 ; 61-70$ years $-28.2 \%$ of men in general in 2017). Conversely, a lower percentage of men aged 71-80 years was found significantly lower percentage $(p<0.05-0.01)$ for VRCPNH (2017 - 19.5\% for men in general and $20.4 \%$ with ischemic stroke; in $2018-13.8 \%$ for men in general and $14.6 \%$ with ischemic stroke; in $2019-12.5 \%$ in men in general and $12.9 \%$ with ischemic stroke) and over 80 years (in $2017-1.6 \%$ in men in general and $1.9 \%$ with ischemic stroke; in $2019-0.7 \%$ in men in general and $0.8 \%$ with ischemic stroke) compared to women of similar groups (71-80 years: in $2017-31.6 \%$ in women in general and $34.2 \%$ with ischemic stroke; in $2018-21.9 \%$ in women in general and $23.5 \%$ with ischemic stroke; in $2019-20.6 \%$ in women in general and $23.7 \%$ with ischemic stroke; over 80 years: in $2017-9.1 \%$ in women in general and $10.3 \%$ with ischemic stroke; in $2019-5.7 \%$ in women in general and $6.6 \%$ with ischemic stroke).

For VCCHEMS in a sex comparison of the percentage of patients of a certain age group found: significantly $(p<0.05)$ higher in men under 40 years of age (2017 - 1.7\% in men in general and $1.6 \%$ with ischemic stroke), $41-50$ years (2018 $-6.8 \%$ in men in general and $5.8 \%$ with ischemic stroke), $51-60$ years $(2017-19.1 \%$ in men in general and $17.9 \%$ with ischemic stroke; in $2018-19.4 \%$ in men in general and $18.1 \%$ with ischemic stroke; in $2019-16.5 \%$ in men in general and $16.7 \%$ in ischemic stroke), $61-70$ years (in $2018-34.8 \%$ in men in general and $36.2 \%$ with ischemia stroke) compared to women of similar groups (up to 40 years: 2017 - $0 \%$ in women in general and $0 \%$ with ischemic stroke; 41 50 years: $2018-2.6 \%$ in women in general and $1.8 \%$ with ischemic stroke; $51-60$ years: in $2017-7.5 \%$ in women in general and $6.8 \%$ with ischemic stroke; in $2018-11.8 \%$ in women in general and $1.7 \%$ with ischemic stroke; in 2019 -
$2.5 \%$ in women in general and $2.0 \%$ of ischemic stroke; 61 70 years: $2018-27.1 \%$ in women in general and $28.0 \%$ with ischemic stroke).

Conversely, a lower percentage of men aged $71-80$ years was found significantly $(p<0.05-0.01)$ for VCCHEMS (2017 $9.5 \%$ in men with hemorrhagic stroke; 2018 - 26.5\% in men in general and $26.4 \%$ with ischemic stroke) and over 80 years (2017 - 10.5\% in men in general and $10.7 \%$ in ischemic stroke; $2018-11.3 \%$ in men in general and $12.0 \%$ in ischemic stroke; $2019-7.1 \%$ in men in general and $7.4 \%$ with ischemic stroke) compared to women of similar groups (71-80 years: in $2017-35.9 \%$ in women with hemorrhagic stroke; in $2018-38.2 \%$ in women in general and $39.4 \%$ with and ischemic stroke; over 80 years of age: in $2017-23.0 \%$ in women in general and $23.6 \%$ with ischemic stroke; in $2018-19.6 \%$ in women in general and $18.8 \%$ with ischemic stroke; in $2019-23.9 \%$ in women in general and $24.8 \%$ with ischemic stroke).

In 2017, the percentage of patients with subarachnoid hemorrhage in VRCPNH was significantly $(p<0.05)$ lower ( $0 \%$ in men and women in general) compared to VCCHEMS (1.1\% in men and $3.0 \%$ in women in general). In 2019, the percentage of women with ischemic stroke in $\mathrm{VRCPNH}$ was significantly $(p<0.05)$ lower, and with intracerebral hemorrhage - significantly $(p<0.05)$ higher $(86.9 \%$ and $12.6 \%$, respectively) compared with VCCHEMS $(93.6 \%$ and $5.5 \%$, respectively).

According to the type of ACA (ischemic, hemorrhagic stroke and subarachnoid hemorrhage) in the dynamics of 2017-2019, no significant differences were found in both hospitals.

The percentage of patients who had a stroke not in the hospital in VRCPNH in 2018 was significantly $(\mathrm{p}<0.05-0.01)$ higher, and in 2019 significantly $(p<0.05-0.01)$ lower (2018 $99.7 \%$ in men in general, $99.6 \%$ with ischemic stroke and $100 \%$ with hemorrhagic stroke; in $2019-87.8 \%$ in men in general and $86.7 \%$ with ischemic stroke, $88.8 \%$ in women in general and $86.2 \%$ with ischemic stroke) compared to VCCHEMS (2018 - 96.8\% in men in general, $97.1 \%$ with ischemic stroke and $94.1 \%$ with hemorrhagic stroke; in 2019 - $94.5 \%$ in men in general and $94.4 \%$ with ischemic stroke, $96.3 \%$ in women in general and $96.1 \%$ with ischemic stroke). The percentage of women who had a stroke in the hospital in VRCPNH in 2019 was significantly $(p<0.05)$ higher $(4.0 \%$ in women in general and $4.6 \%$ with ischemic stroke) compared to VCCHEMS $(0.6 \%$ in women in general and $0.7 \%$ with ischemic stroke).

In VRCPNH, the percentage of patients who had a nonhospital stroke in 2018 was significantly $(p<0.05-0.01)$ higher than in 2017 and 2019 (2017 - 94.8\% in men in general and $94.8 \%$ with ischemic stroke, $96.2 \%$ in women in general and $95.7 \%$ with ischemic stroke; $2018-99.7 \%$ in men in general and $99.6 \%$ with ischemic stroke, $98.9 \%$ in women in general and $98.8 \%$ with ischemic stroke; $2019-87.8 \%$ in men in general and $86.7 \%$ with ischemic stroke, $88.8 \%$ in women in general and $86.2 \%$ with ischemic stroke). In 
VRCPNH, the percentage of patients who had a stroke in the hospital in 2018 was significantly $(p<0.05-0.01)$ lower than in 2017 and 2019 (2017 - 5.2\% in men in general and $5.2 \%$ with ischemic stroke, $4.3 \%$ in women with ischemic stroke; $2018-0.3 \%$ in men in general and $0 \%$ in ischemic stroke, $0 \%$ in women with ischemic stroke; $2019-2.4 \%$ in men in general and $2.8 \%$ with ischemic stroke, $4.6 \%$ in women with ischemic stroke).

In VCCHEMS the percentage of patients who had a stroke in the hospital in 2017 was significantly ( $p<0.05-0.01)$ higher than in 2018 and 2019 (2017 - 4.0\% in men in general and $3.6 \%$ with ischemic stroke, $6.3 \%$ in women in general and $6.4 \%$ with ischemic stroke; $2018-1.3 \%$ in men in general and $1.1 \%$ with ischemic stroke, $2.0 \%$ in women in general and $1.8 \%$ with ischemic stroke; $2019-0.6 \%$ in women in general and $0.7 \%$ with ischemic stroke).

It is impossible to correctly compare the percentage of patients with atrial fibrillation between the two institutions and in the dynamics of each hospital due to the lack of data in case histories (no atrial fibrillation screening was performed).

In VCCHEMS the percentage of patients who had a stroke in winter was found to be significantly $(p<0.05-0.01)$ higher in 2018 and significantly ( $p<0.05-0.001)$ lower - in 2019 (2018 - $30.6 \%$ in men in general and $30.4 \%$ with ischemic stroke; $2019-8.6 \%$ in men with ischemic stroke, $7.4 \%$ in women in general, $7.8 \%$ with ischemic stroke and $20.0 \%$ with hemorrhagic stroke) compared to VRCPNH (2018 - 21.8\% in men in general and $20.6 \%$ with ischemic stroke; 2019 $16.5 \%$ in men with ischemic stroke, $23.4 \%$ in women in general, $21.7 \%$ with ischemic stroke and $34.8 \%$ with hemorrhagic stroke).

In 2018, the percentage of patients who suffered a stroke in the spring was significantly lower in VCCHEMS $(p<0.05-$ $0.01)(18.4 \%$ in men in general and $18.8 \%$ in ischemic stroke, $8.3 \%$ in women with hemorrhagic stroke) compared to with VRCPNH $(26.6 \%$ in men in general and $28.5 \%$ in ischemic stroke, $33.3 \%$ in women with hemorrhagic stroke).

In 2019, the percentage of patients who suffered a stroke in the autumn was found to be significantly $(p<0.05)$ higher in VCCHEMS $(21.4 \%$ in men in general and $25.0 \%$ in hemorrhagic stroke) compared to VRCPNH (13.6\% in men in general and $5.1 \%$ with hemorrhagic stroke).

In VRCPNH in 2017, the percentage of women who suffered an ischemic stroke in winter in 2017 was significantly $(p<0.05)$ lower than in 2018 (2017 - 19.1\% in women in general and $17.4 \%$ with ischemic stroke; $2018-27.8 \%$ in women in general and $28.3 \%$ with ischemic stroke). In 2019 , compared to 2017 and 2018, there was a significantly lower $(p<0.05)$ percentage of men who suffered from hemorrhagic stroke in winter (2017 - 23.1\% of men in general and $35.1 \%$ with hemorrhagic stroke; $2018-21.9 \%$ in men in general and $28.9 \%$ with hemorrhagic stroke; $2019-15.0 \%$ in men in general and $5.1 \%$ with hemorrhagic stroke).

In VRCPNH in 2017 and 2018, the percentage of patients who fell ill in the spring was significantly lower $(p<0.05)$ compared to 2019 (2017 - 29.7\% in men with hemorrhagic stroke; $2018-26.6 \%$ in men in general and $15.6 \%$ with hemorrhagic stroke, $18.7 \%$ in women in general and $16.9 \%$ with ischemic stroke; $2019-35.2 \%$ in men in general and $53.8 \%$ in hemorrhagic stroke, $29.1 \%$ in women in general and $31.6 \%$ with ischemic stroke). In the current season of the year, the percentage of women with ischemic stroke was significantly $(p<0.05-0.01)$ higher in 2017 compared to 2018 (2017 - 28.2\% in women in general and $28.8 \%$ in ischemic stroke; in $2018-18.7 \%$ in women in general and $16.9 \%$ with ischemic stroke).

In VRCPNH in 2017 and 2018, the percentage of men who fell ill in the summer was significantly lower $(p<0.05-$ 0.001 ) compared to 2019 (2017 - 26.7\% in men in general and $27.5 \%$ with ischemic stroke; $2018-23.7 \%$ in men in general and $24.3 \%$ with ischemic stroke; $2019-36.2 \%$ in men in general and $35.3 \%$ with ischemic stroke). In the current season of the year, the percentage of women with ischemic stroke was significantly $(p<0.05-0.01)$ higher in 2017 compared to 2018 (2017 - 31.1\% in women in general and $33.2 \%$ with ischemic stroke; $2018-21.9 \%$ in women in general and $22.9 \%$ with ischemic stroke).

In VRCPNH in 2018 and 2019, the percentage of patients who fell ill in autumn was significantly lower $(p<0.05-0.001)$ compared to 2017 (2017 - 18.2\% in men in general, 18.6\% with ischemic stroke and $16.2 \%$ with hemorrhagic stroke, $21.5 \%$ in women in general and $20.7 \%$ with ischemic stroke; $2018-27.9 \%$ in men in general, $26.6 \%$ with ischemic stroke and $35.6 \%$ with hemorrhagic stroke, $31.6 \%$ in women in general and $31.9 \%$ with ischemic stroke; $2019-13.6 \%$ for men in general, $14.9 \%$ with ischemic stroke and $5.1 \%$ with hemorrhagic stroke, $19.4 \%$ for women in general and $18.4 \%$ with ischemic stroke).

In VCCHEMS in 2019, the percentage of women who had an ischemic stroke in winter was significantly $(p<0.001)$ lower than in 2017 and 2018 (2017 - 26.5\% in men in general and $27.3 \%$ in ischemic stroke, $22.7 \%$ in women in general and $23.6 \%$ with ischemic stroke; $2018-30.6 \%$ in men in general and $30.4 \%$ in ischemic stroke, $26.5 \%$ in women in general and $26.6 \%$ with ischemic stroke; $2019-9.9 \%$ in men in general and $8.6 \%$ with ischemic stroke, $7.4 \%$ in women in general and $7.8 \%$ with ischemic stroke).

In VCCHEMS in 2018, the percentage of patients who fell ill in the spring was significantly lower $(p<0.05-0.001)$ compared to 2017 (2017 - 27.9\% in men in general and $26.9 \%$ in ischemic stroke, $26.9 \%$ in women in general and $28.2 \%$ with hemorrhagic stroke; $2018-18.4 \%$ in men in general and $18.8 \%$ in ischemic stroke, $19.6 \%$ in women in general and $8.3 \%$ with hemorrhagic stroke). In the current season of the year, the percentage of patients with ischemic stroke in 2019 was significantly higher $(p<0.05-0.001)$ compared to 2017 and 2018 (2017 - 27.9\% in men in general and $26.9 \%$ in ischemic stroke, $26.9 \%$ in women in general and $26.7 \%$ with ischemic stroke; $2018-18.4 \%$ in men in general and $18.8 \%$ with ischemic stroke, $19.6 \%$ in women in general and $20.6 \%$ with ischemic stroke; $2019-34.1 \%$ in 
men in general and $34.6 \%$ with ischemic stroke, $38.0 \%$ in women in general and $38.6 \%$ with ischemic stroke).

In VCCHEMS in 2018, the percentage of women who fell ill in the summer was significantly lower $(p<0.05-0.001)$ compared to 2018 and 2019 (2017 - 31.3\% in women in general, $30.7 \%$ with ischemic stroke and $38.5 \%$ with hemorrhagic stroke; $2018-22.5 \%$ in women in general, $23.4 \%$ with ischemic stroke and $12.5 \%$ with hemorrhagic stroke; 2019 - 36.8\% in women in general, 35.9\% with ischemic stroke and $50.0 \%$ with hemorrhagic stroke).

In VCCHEMS in 2017 and 2019, the percentage of patients who fell ill in the autumn was significantly lower $(p<0.05-0.001)$ than in 2018 (2017 - 16.8\% in men in general and $16.6 \%$ with ischemic stroke, $19.1 \%$ in women in general, $19.3 \%$ with ischemic stroke and $17.9 \%$ with hemorrhagic stroke; $2018-23.2 \%$ in men in general and $22.8 \%$ with ischemic stroke, $31.4 \%$ in women in general, $29.4 \%$ with ischemic stroke and $54.2 \%$ with hemorrhagic stroke; 2019 $-21.4 \%$ for men in general and $21.0 \%$ with ischemic stroke, $17.8 \%$ for women in general and $17.6 \%$ with ischemic stroke).

When analyzing case histories for 2018-2019, information on the presence or absence of symptoms of carotid artery stenosis does not reflect the real picture of this indicator. More than $90 \%$ of documents do not contain the necessary data and are marked as "unknown".

When comparing in 2017 the percentage of patients who had symptoms of carotid artery stenosis found significantly $(p<0.05-0.001)$ lower in patients of VCCHEMS $(2.0 \%$ in men in general and $2.3 \%$ with ischemic stroke, $1.2 \%$ in women in general and $1.0 \%$ with ischemic stroke) compared with VRCPNH $(8.8 \%$ in men in general and $10.0 \%$ in ischemic stroke, $4.3 \%$ in women in general and $4.9 \%$ with ischemic stroke).

\section{Discussion}

Stroke is considered an age-dependent disease. Ukraine is significantly ahead of not only the CIS countries, but also the countries of Eastern Europe in the number of people over the age of $65(13.9 \%)$, so it is one of the "oldest" countries in Europe [24]. The gender and age structure of the country's population is characterized by a significant predominance of women in older age groups, due to the excessive mortality of men of working age and low rates of their ability to live to retirement age [10]. The average life expectancy of men is significantly lower than the average life expectancy of women. In addition, the influence of demographic losses in the war and post-war times is still noticeable in the oldest age groups [22].

The gender imbalance of the population increases with age. Because the average life expectancy of women is longer than that of the opposite sex, they are more likely to suffer a stroke in old age. Men get sick and die from ACA more often than women, especially under 60 years of age. The combination of a larger number of factors compared to women significantly increases the risk of stroke in men of young working age [4].

Interesting is the fact that in the age group up to 70 years the percentage of men is higher than that of women. This difference in older age (over 70 years) becomes the opposite. In addition, it was found that in VRCPNH compared with VCCHEMS dominated by younger patients (up to 70 years). This is due to the fact that VRCPNH had more logistical and organizational conditions for thrombolysis, which is known to occur more often in young and middle-aged patients.

In the period of 2017-2019 in both hospitals we noted an increase over time in the percentage of patients aged group 1-4 and a decrease of 5-6.

Large-scale statistical studies of the number of hospitalizations with ischemic stroke among people aged 18-54 have shown disappointing results: the number of young patients has increased significantly. If earlier elderly people were considered a risk group for stroke, now $10 \%$ of all cases are young [12]. In addition, studies have shown that at a young age, stroke is more common in men (growth among all age groups is about $50 \%$ ). As for females, with age the risk of developing ACA in them is $30 \%$ higher [17]. Similar trends are observed in our study: the percentage of young and middle-aged men is higher than women.

Risk factors for stroke - high blood pressure, diabetes, hypercholesterolemia, atrial fibrillation, carotid artery stenosis, unhealthy lifestyle associated with smoking, alcohol, drugs, obesity and more. If precautionary measures are not taken, ischemic stroke may soon become a typical disease of young people [11].

It is extremely important to conduct additional examinations in risk groups and to analyze the presence of ACA factors and health problems in patients who have already had a stroke.

Yu.A. Dolgusheva [6] for the first time obtained representative regional data on seasonality: hemorrhagic stroke is statistically more common in winter and spring, and ischemic stroke - in summer and autumn.

Opinions of scientists on this issue are different. One group of researchers noted an increase in the incidence of this pathology and mortality in the cold months (winter and spring) and a decrease in these indicators in summer and autumn [7, 14, 23], the other denied the seasonal frequency of its occurrence, arguing that the incidence of stroke depends not on the specific season, but on social and meteorological conditions [19, 20, 21]. Thus, the deterioration of meteorological conditions (magnetic storms, worsening weather conditions, sharp and significant changes in air temperature and atmospheric pressure) causes exacerbation or complication of the disease in people with cardiovascular pathology.

In the comparative analysis, we were interested in more differences in the dynamics of 2017-2019 within each hospital. Numerous significant differences were found between the years of the study in the percentage of patients admitted in a given season, and in both hospitals they had similar trends. This forces us to agree with the conclusions 
reached by the second group of researchers (meteorological dependence of stroke).

A positive point in the organizational and diagnostic work of VCCHEMS should be noted the decrease over time in the percentage of patients whose stroke occurred in a nonspecialized department.

There is a hereditary burden of ACA. The risk of stroke increases if the parents have had a stroke. However, in a global study conducted by Feigin V.L. et al. [9] in 188 countries, it was found that more than $90 \%$ of the risk of ACA is due to modified factors.

Unfortunately, in the course of our prospective study, we were only able to dispose of the anamnestic data provided by doctors during the examination and communication with the patient or his relatives. And even an attempt to analyze for factors such as atrial fibrillation and carotid artery stenosis (we are no longer talking about the full range of modified factors) was unsuccessful because the data were collected incorrectly and incompletely.

Thus, the analysis of risk factors for stroke suggests

\section{References}

[1] Bokeryia, L. A., Pokrovskyi, A. V., Sokurenko, G. Yu., Samorodskaia, I. V., Abuhov, S. A., \& Alekian, B. G. (2013). National guidelines for the management of patients with brachiocephalic artery disease. Russian consensus document.

[2] Chechulov, P. V., Vozniuk, I. A., Soroka, V. V., Varaksyna, E. A., Aidaev, S. S., \& Zenyn, A. V. (2013). Carotid endarterectomy in the first days after an ischemic stroke is safe and warranted. Thoracic and Cardiovascular Surgery, 3, 24-29.

[3] Christensen, A. L., Rasmussen, L. H., Baker, M. G., Lip, G. Y. H., Dethlefsen, C., \& Larsen, T. B. (2012). Seasonality, incidence and prognosis in atrial fibrillation and stroke in Denmark and New Zealand. BMJ, 2(4), 1-8. doi: http://dx.doi.org/10.1136/ bmjopen-2012-001210

[4] Cordonnier, C., Sprigg, N., Sandset, E. C., Pavlovic, A., Sunnerhagen, K. S., \& Caso, V. (2017). Women Initiative for Stroke in Europe (WISE) Group. Stroke in women - from evidence to inequalities. Nat. Rev. Neurol., 13, 521-532.

[5] de Steenhuijsen Piters, W. A., Algra, A., van den Broek, M., F., Dorhout Mees, S. M., \& Rinkel, G. J. (2013). Seasonal and meteorological determinants of aneurysmal subarachnoid hemorrhage: a systematic review and meta-analysis. J Neurol., 260(2), 614-619. doi: 10.1007/s00415-012-6687-z

[6] Dolhusheva, Yu. A. (2015). Study of the influence of environmental risk factors on the development of stroke in residents of Rostovon-Don. In the materials of the VI International Scientific and Practical Conference: Rostov-on-Don.

[7] Dolhusheva, Yu. A. (2016). Comprehensive analysis of the influence of exogenous risk factors on various types of cerebral stroke, considering the phases of the solar cycle. In the collection of materials of the Youth Scientific Society of Rostov State Medical University, Rostov-on-Don (61-63 pp.). Rostovon-Don.

[8] Etches, V., Frank, J., Ruggiero, E. D., \& Manuel, D. (2006). Measuring population health: a review of indicators. Ann. Rev. Public Health, 27, 29-55. doi: 10.1146/ annurev.publhealth.27.021405.102141

[9] Feigin, V. L., Roth, G. A., Naghavi, M., Parmar, P., Krishnamurthi, R., Chugh, S., ... Estep, K. (2016). Global burden of stroke and that the disease is based on various causes, the contribution of which researchers assess differently. A serious and balanced attitude to the collection and analysis of information is important for the preventive organization of the fight against this serious disease.

\section{Conclusions}

1. When comparing the data of the territorial-population register of stroke in hospitals of Vinnytsia in 2017-2019, it was found that in both studied institutions the percentage of young and middle-aged patients, especially men, increased. The percentage of young and middle-aged patients in VRCPNH is higher than in VCCHEMS.

2. There were no significant differences in the dynamics of stroke in both hospitals. The percentage of patients who had a stroke in hospital has decreased over time. The meteorological dependence of stroke has been proved, which points to the importance of preventive measures for people at risk. The main shortcomings in the collection of anamnestic data are analyzed.

risk factors in 188 countries, during 1990-2013: a systematic analysis for the Global Burden of Disease Study 2013. The Lancet Neurology, 15(9), 913-924. doi: https://doi.org/10.1016/ S1474-4422(16)30073-4

[10] Foint, N. A. (2002). Life expectancy in old age: Evolution, modernity, prospects. K.

[11] Furie, K. L., Kasner, S. E., Adams, R. J., Albers, G. W., Bush, R. L., Fagan, S. C., ... Mitchell, P. H. (2011). Guidelines for the prevention of stroke in patients with stroke or transient ischemic attack: a guideline for healthcare professionals from the American Heart Association/American Stroke Association. Stroke, 42(1), 227-276. doi: 10.1161/STR.0b013e3181f7d043

[12] George, M. G., Tong, X., \& Bowman, B. A. (2017). Prevalence of Cardiovascular Risk Factors and Strokes in Younger Adults. JAMA Neurology, 74(6), 695-703. doi: 10.1001/ jamaneurol.2017.0020

[13] Kaerova, E. V., Zhuravskaia, N. S., Matveeva, L. V., \& Shestjora, A. A. (2017). Analysis of the main risk factors for stroke. Modern problems of science and education, 6. https://www.scienceeducation.ru/ru/article/view?id=27342

[14] Khan, F. A., Engstrom G., Jerntorp I., Pessah-Rasmussen, H., \& Janzon, L. (2005). Seasonal patterns of incidence and case fatality of stroke in Malmo, Sweden: The STROMA Study. Neuroepideimology, 24(1-2), 26-31. doi: 10.1159/000081046

[15] Kliuchykhyna, O. A., \& Stakhovskaia, L.V. (2014). Analysis of epidemiological indicators of stroke according to the data of territorial population registers 2009-2012. Journal of Neurology and Psychiatry named after S. S. Korsakov, 114(6), 63-69.

[16] Kuročka, M., Rusňák, F., Beňo, P., Horný, L., Podolec, M., \& Rusňák, M. (2016). Urgentné a emergentné operácie karotických artérií. Vask. Med., 8(1), 17-20.

[17] Martirosyan, V., \& Krupskaya, J. (2013). Study of the Factors Influencing Mortality from the Cerebral Stroke in Patients of Different Ages. Journal of Medicine and Medical Research, 3(4), 1530-1557. doi: https://doi.org/10.9734/BJMMR/2013/3991

[18] Martsevych, S. Yu., Kutyshenko, N. P., Suvorov, A. Yu., Gynzburh, M. L., Deev, A. D., \& Boitsov, S. A. (2015). Analysis of anamnestic factors and their role in determining the closest 
(hospital) prognosis in patients after a stroke or transient ischemic attack. LIS-2 register results. Russian Journal of Cardiology, 6(122), 14-19.

[19] Martyrosian, V. V., \& Dolhusheva, Yu. A. (2016). A probabilistic analysis of the influence of exogenous risk factors on the incidence of hemorrhagic strokes, considering the period of solar activity. Journal of Fundamental Medicine and Biology, 1, 52-59.

[20] Sipilä, J. O., Ruuskanen, J. O., Kauko, T., Rautava, P., \& Kytö, V. (2017). Seasonality of stroke in Finland. Ann Med., 49(4), 310318. doi: https://doi.org/10.1080/07853890.2016.1254350

[21] Starodubtseva, O. S., Behycheva, S. V., Shyrokov, V. A., Osynkyn, G. A., \& Rzhanykova, D. D. (2017). The influence of meteorological factors on the seasonality of stroke in Yekaterinburg. Ural Medical Journal, 10, 66-70.

[22] Steshenko, V. S. (2003). Birth rate/Population of Ukraine-2002. Annual analytical report. K.: Institute of Demography and Social Research of the National Academy of Sciences of Ukraine,
50-51.

[23] Takizawa, S., Shibata, T., Takagi, S., Kobayashi, S., \& Japan Standard Stroke Registry Study Group. (2013). Seasonal variation of stroke incidence in Japan for 35631 stroke patients in the Japanese Standard Stroke Registry, 1998-2007. Journal of Stroke and Cerebrovascular Diseases, 22(1), 36-41. doi: 10.1016/j.jstrokecerebrovasdis.2011.06.005

[24] Thrift, A. G., Thayabaranathan, T., Howard, G., Howard, V. J., Rothwell, P. M., Feigin, V. L., ... Cadilhac, D. A. (2017). Global stroke statistics. Int. J. Stroke, 12(1), 13-32. doi: 10.1177/ 1747493016676285

[25] Turin, T. C., Kita, Y., Murakami, Y., Rumana, N., Sugihara, H., Morita, Y., ... Ueshima, H. (2008). Abbott and Hirotsugu Ueshima Higher Stroke Incidence in the Spring Season Regardless of conventional Risk Factors: Takashima Stroke Registry, Japan, 1988-2001. Stroke, 39(3), 745-752. doi: 10.1161/ STROKEAHA.107.495929

\section{АНАЛІЗ ЧИННИКІВ РИЗИКУ ТА СТРУКТУРА ІНСУЛЬТУ ЗА ДАНИМИ ГОСПІТАЛЬНОГО РЕГІСТРУ ЛІКАРЕНЬ ВІННИЦІ ЗА 2017-2019 РОКИ \\ Фікс Д.О.}

Завдяки реалізації аналізу цілого комплексу показників якості надання медичної допомоги при гострому порушенні мозкового кровообігу i, насамперед, визначення основних недоліків у веденні інсультного регістру, можливо скоротити захворюваність, смертність та інвалідність від даної нозології. Мета роботи - вивчити та порівняти структуру та чинники ризику мозкового інсульту за даними лікарень м. Вінниці за період 2017-2019 рр. Інсультний регістр створено на основі медичної документації стаціонарів Комунального некомерційного підприємства "Вінницька обласна клінічна психоневрологічна лікарня ім. акад. О.І. Ющенка Вінницької обласної ради" (ВОКПЛ) та Вінницької міської клінічної лікарні швидкої медичної допомоги (ВМКЛШМД), які є найбільш типовими для зазначеного регіону України. Статистична обробка результатів здійснена за допомогою ліцензійного статистичного пакету "Statistica 5.5" з використанням параметричних методів оцінки. Між двома лікувальними закладами м.Вінниця та в динаміці часу встановлені достовірні відмінності у різного за віком, статтю, типом інсульту контингенту пацієнтів. При порівнянні даних територіально-популяційного регістра інсульту в лікарнях м.Вінниця в 2017-2019 рр. встановлено, що в обох досліджуваних закладах збільшилась відсоткова частка хворих молодого і середнього віку, в особливості чоловіків. У ВОКПЛ, порівняно з ВМКЛШМД, більша відсоткова частка пацієнтів молодого та середнього віку. Проаналізовано модифіковані чинники ризику, які в даний час є найважливішою медико-соціальною проблемою. За типом інсульту в динаміці в обох лікарнях суттєвих відмінностей не відмічалось. Відсоткова частка пацієнтів, у котрих інсульт виник у лікарні, з часом зменшилась. Доведено метеозалежність інсульту, що вказує на важливість превентивних заходів для осіб даної групи ризику. Проаналізовано основні недоліки при зборі анамнестичних даних. Аналіз чинників ризику інсульту дає підставу вважати, що в основі виникнення захворювання лежать різні причини.

Ключові слова: інсульт, гендерні відмінності, чинники ризику інсульту, метод регістру.

\section{АНАЛИЗ ФАКТОРОВ РИСКА И СТРУКТУРА ИНСУЛЬТА ПО ДАННЫМ ГОСПИТАЛЬНОГО РЕГИСТРА БОЛЬНИЦ ВИННИЦЫ ЗА 2017-2019 ГОДЫ Фикс Д.А.}

Благодаря реализации анализа целого комплекса показателей качества оказания медицинской помощи при остром нарушении мозгового кровообращения и, прежде всего, определении основных недостатков в ведении инсультного регистра, возможно сократить заболеваемость, смертность и инвалидность от данной нозологии. Цель работы - изучить и сравнить структуру и фракторы риска мозгового инсульта по данным больниц г.Винницы за период 2017-2019 г2. Инсультный регистр создан на основе медицинской документации стационаров Коммунального некоммерческого предприятия "Винницкая областная клиническая психоневрологическая больница им. акад. А.И. Ющенко Винницкого областного совета" (ВОКПБ) и Винницкой городской клинической больницы скорой медицинской помощи (ВГКБСМП), которые являются наиболее типичными для данного региона Украины. Статистическая обработка результатов осуществлена с помощью лицензионного статистического пакета "Statistica 5.5" с использованием параметрических методов оценки. Между двумя лечебными заведениями г. Винница и в динамике времени установлены достоверные различия у разного по возрасту, полу, типу инсульта контингента пациентов. При сравнении данных территориально-популяционного регистра инсульта в больницах 2. Винницы в 2017-2019 г2. установлено, что в обоих исследуемых учреждениях увеличилась процентная доля больных молодого и среднего возраста, в особенности мужчин. В ВОКПБ сравнению с ВГКБСМП большая процентная доля пациентов молодого и среднего возраста. Проанализированы модифицированные факторы риска, которые в настоящее время являются важнейшей медико-социальной проблемой. По типу инсульта в динамике в обеих больницах существенных различий не отмечалось. Процентная доля пациентов, у которых инсульт возник в больнице, со временем уменьшилась. Доказано метеозависимость инсульта, что указывает на важность превентивных мер для лиц данной группы риска. Проанализированы основные недостатки в сборе анамнестических данных. Анализ факторов риска инсульта дает основание считать, что в основе возникновения заболевания лежат разные причины.

Ключевые слова: инсульт, гендерные различия, фракторы риска инсульта, метод регистра. 